\title{
PAS: Pendidikan, Arahan, dan Sinergi menuju Indonesia Emas
}

\author{
Vanessa Arieputri \\ Universitas Katolik Indonesia Atma Jaya \\ arieputrivanessa@gmail.com
}

\begin{abstract}
Abstrak
Indonesia sedang memasuki periode bonus demografi pada tahun 2028. Hal ini ditandai dengan lebih besarnya jumlah penduduk usia produktif (berusia 15-64 tahun) dibanding penduduk usia tidak produktif (berusia di bawah 15 tahun dan di atas 64 tahun). Meningkatnya penduduk usia produktif ini dapat menjadi tantangan, namun juga berdampak positif terhadap meningkatnya perekonomian negara. Dalam mencapai pertumbuhan ekonomi dan stabilitas negara yang maksimal ini, diperlukan solusi yang menyeluruh dan disertai dengan sinergi antara penduduk dengan pemerintah. Berdasarkan hal tersebut, penulis bertujuan untuk menggagas solusi berupa PAS: Pendidikan, Arahan, dan Sinergi menuju Indonesia Emas. Pendekatan ini menyasar kepada pendidikan sebagai landasan dalam kunci penduduk dalam menyesuaikan diri dengan perkembangan global, arahan yang berasal dari institusi pemerintahan yang kuat, serta sinergi antar institusi pemerintahan. bertepatan dengan usainya Sustainable Development Goals pada akhir tahun 2030, bonus demografi dapat menjadi pencapaian emas bagi Indonesia.
\end{abstract}

Kata kunci: Bonus Demografi; Institusi; Pembangunan Ekonomi; Pendidikan; Sinergi; Sustainable Development Goals (SDG)

\section{Latar Belakang}

Final Liga Champion 1999 yang mempertemukan Manchester United dengan Bayern Munich merupakan salah satu momen paling ajaib dan tidak masuk akal dalam sejarah persepakbolaan dunia. Tertinggal 1-0 dengan tiga menit tersisa, seluruh penonton sudah cukup yakin bahwa Manchester United akan kalah dari Bayern Munich dan gagal memperoleh treble yang diimpi-impikan. Tiga menit. Lalu bagaikan keajaiban, pada menit ke-90 detik ke-36, tendangan sudut yang berujung gol dari Manchester United itu memaksa Bayern untuk bermain di extra time. Nyatanya kurang dari 2 menit setelahnya gol penentu dari Ole Gunnar Solksjaer malah memupuskan harapan Bayern untuk memenangkan Liga Champion yang tadinya sudah di tangan mereka.

Alex Ferguson sebagai pelatih dari Manchester United pada masa itu sebenarnya memperoleh banyak sekali kritik melalui pilihan timnya. Bukan hanya dari para petinggi klub, namun juga dari para fans. Hal ini disebabkan karena kenekatannya dalam memainkan banyak sekali pemain muda yang 
notabenenya masih tidak berpengalaman. Namun salah satu poin yang selalu Ferguson tekankan kepada para pemain mudanya adalah bagaimana ia berharap anak-anak didiknya selalu dapat bermain dengan lepas, tahu dengan jelas apa tujuan yang ingin mereka capai, yaitu kemenangan, dan yang terutama adalah bermain dengan terus menjadi lebih baik setiap harinya. Final Liga Champion tersebut, meskipun tidak dapat kita urungkan juga merupakan sebuah keberuntungan, namun menunjukkan bahwa ketika diberikan kepercayaan, anak-anak muda yang tidak memiliki pengalaman sekalipun dapat menaklukan dunia.

Situasi di atas cukup serupa dengan perubahan yang terjadi. Di tengah perubahan dunia yang begitu ekstrim terjadi di tahun 2020, banyak sekali permasalahan baik dalam skala nasional maupun internasional yang terjadi dan melemahkan stabilitas dan perekonomian Indonesia. Banyak sekali keraguan yang muncul, apakah Indonesia dapat kembali bangkit dan berjaya seperti sedia kala? Apakah perekonomian dan pendapatan negara Indonesia akan mengalami penurunan? Indonesia sesungguhnya masih memiliki kunci tersembunyi untuk menjaga stabilitas dan perekonomian negara, yaitu periode bonus demografi.

Bonus demografi merupakan sebuah periode di mana jumlah penduduk usia produktif di sebuah negara lebih banyak dibandingkan penduduk non-produktif (Utomo, 2019). Penduduk usia produktif sendiri berarti penduduk berusia 15-64 tahun yang sedang aktif bekerja dan yang sedang tidak bekerja (LIPI, 2014). Diprediksi bahwa pada puncak bonus demografi yaitu tahun 2028 hingga 2031 (Setiawan, 2016), penduduk usia produktif diproyeksikan akan mencapai $64 \%$ dari total jumlah penduduk yang akan menyentuh angka 297 juta jiwa. Keadaan ini dapat dimaknai sebagai peluang Indonesia untuk berkembang dalam berbagai aspek karena besarnya proporsi penduduk produktif. Besarnya proporsi penduduk produktif ini juga seringkali dikaitkan dengan peluang sebuah negara untuk meningkatkan pertumbuhan ekonomi (LIPI, 2014).

Pertumbuhan ekonomi ini disebabkan tingginya jumlah penduduk produktif maka tenaga kerja yang ada juga akan banyak, sehingga akan meningkatkan pendapatan negara. Meningkatnya jumlah usia produktif juga tentunya akan meningkatkan daya beli penduduk sehingga menciptakan lapangan usaha yang baru serta investasi dari dalam dan luar negeri. Selain menopang dan meningkatkan ekonomi nasional, bonus demografi juga dapat membantu meningkatnya stabilitas negara dan kesejahteraan penduduk Indonesia.

Mengapa stabilitas negara menjadi sesuatu yang penting? Saat ini, salah satu konflik mengancam persatuan dan kesatuan Indonesia adalah intoleransi. Mahfud M.D., ketua Mahkamah Konstitusi periode 2008-2013 mengatakan bahwa gejala perpecahan semakin terasa akibat adanya politik identitas dan hoaks yang menyebabkan penduduk yang terpolarisasi (Wicaksono, 2019). Artinya, perlu ada tindakan yang dilakukan untuk menjaga kesatuan dan persatuan bangsa. 
Berdasarkan penelitian Utomo (2019) terkait kepercayaan generasi muda Indonesia terhadap Pancasila, 81,5\% dari generasi muda mendukung Pancasila. Artinya, mayoritas generasi muda mendukung nilai-nilai toleransi dan persatuan yang terkandung di dalam Pancasila. Hal ini menjadi modal yang baik untuk mempertahankan kesatuan dan persatuan bangsa. Studi lainnya yang berdasarkan penelitian Adinugroho, Dwifatma, Gani, dan Simartama (2019) juga menekankan bahwa $44 \%$ generasi muda tidak menyukai politisasi agama, $11 \%$ tidak menyukai radikalisme, dan $22 \%$ tidak menyukai hoaks. Dengan kata lain, terdapat peluang yang sangat besar bagi Indonesia untuk menjadi negara yang aman dan saling bertoleransi.

Secara teoritis hasil penelitian terkait karakteristik generasi muda disertai dengan periode bonus demografi ini akan membuka peluang yang besar bagi penduduk Indonesia untuk hidup lebih sejahtera. Hal ini juga didukung dengan riset yang menyebutkan bahwa hampir sebagian besar dari penduduk Indonesia akan memperoleh pekerjaan berkualitas sehingga beban keuangan penduduk dan negara akan semakin ringan (The Jakarta Post, 2018). Hal ini tentu membawa angin segar untuk peningkatan perekonomian dan stabilitas negara.

Namun disisi lain, meningkatnya penduduk usia produktif ini meningkatkan kekhawatiran bahwa Indonesia akan mengalami kesulitan menyediakan tenaga kerja raksasa dengan pekerjaan yang cukup. Hal ini disebabkan karena pertumbuhan ekonomi yang hanya akan berkisar 5\% sebelum memuncaknya periode bonus demografi (The Jakarta Post, 2018). Berkaca dari Filipina yang gagal memanfaatkan bonus demografi, Indonesia perlu juga mempertimbangkan strategi dalam memanfaatkan periode ini dengan maksimal.

\section{Belajar dari Sahabat-sahabat Kita}

Filipina yang memiliki lebih dari 100 juta penduduk mendapatkan pendapatan GDP sebesar 7.2\% di tahun 2013, tertinggi di Asia Tenggara (Nikkei Asian Review, 2014). Namun angka ini tidak berbanding lurus dengan tingkat pengangguran yang mencapai $7 \%$ dari total penduduknya. Angka ini diperburuk dengan catatan bahwa 30\% dari penduduk diklasifikasikan sebagai berkekurangan, dan hidup hanya dengan satu dollar setiap harinya. Setelah dilakukan penelitian lebih lanjut, kegagalan Filipina dalam memanfaatkan bonus demografi ini disebabkan karena ketidaktersediaan lapangan pekerjaan yang layak untuk menampung tenaga kerja yang tersedia. Akhirnya sumber pendapatan terbesar hanya diperoleh Filipina dari pendapatan 10 juta penduduknya yang bekerja di luar negeri. Hal ini mengganggu siklus untuk peningkatan pendapatan domestik dan investasi dari dalam dan luar negeri.

Terdapat juga beberapa negara seperti Tiongkok, Jepang, dan Korea yang berhasil dalam memanfaatkan periode bonus demografi dalam meningkatkan pendapatan negaranya. Mantan Menteri 
Koordinator bidang Kesejahteraan Penduduk (Menko Kesra) Haryono Suyono menyebutkan, keberhasilan Tiongkok dapat dilihat dari industri rumah tangga mereka yang meningkat pesat, serta kegiatan produksi berbagai komponen peralatan elektronika sehingga menciptakan lapangan pekerjaan yang sangat luas bagi penduduknya (Aditiasari, 2015). Sedangkan Korea Selatan berhasil mengarahkan industri-industri rumah tangganya untuk membuat komponen telepon genggam untuk dirakit kemudian di pabrik. Hal ini menunjukkan hubungan saling ketergantungan dan melengkapi antara industri rumah tangga dengan industri skala besar yang secara tidak langsung juga memperluas kesempatan lapangan pekerjaan bagi penduduknya.

Dalam Seminar Nasional "Pengembangan SDM Unggul untuk Memanfaatkan Peluang Bonus Demografi Menuju Indonesia Maju pada RPJMN 2020-2024”, Menteri Perencanaan Pembangunan Nasional/Kepala Bappenas Bambang PS Brodjonegoro juga mengatakan bonus demografi tidak boleh dilewatkan. Beliau memberi contoh kemajuan Jepang yang sangat luar biasa setelah bonus demografi. Sebagai contohnya, Jepang dapat menjadi tuan rumah Olimpiade di tahun 1964, yang artinya 20 tahun setelah kotanya hancur karena bom. Di tahun 1960, Jepang membuat kereta cepat, ketika pendapatan per kapita sama dengan Indonesia saat ini.

Berbekal pengalaman beberapa negara dalam menghadapi bonus demografi, Indonesia memperoleh keuntungan karena dapat mencontoh hal-hal yang sudah dilakukan berbagai negara maju dan kemudian dapat mengembangkannya menjadi lebih baik lagi. Pun berdasarkan hasil penelitian kita sudah dapat menyimpulkan bahwa kunci dari kesuksesan perkembangan negara ini terletak pada kualitas SDM (Umah, 2019). Sumber daya Jepang dan Korea Selatan jelas kalah dengan Indonesia dari segi kuantitas. Namun, mereka mampu mengembangkan SDM dengan memanfaatkan bonus demografi. Hal ini menunjukkan apabila Indonesia sungguh-sungguh dalam mengembangkan Sumber Daya Manusia penduduknya, maka bukan tidak mungkin Indonesia bisa menjadi negara yang lebih maju dari Tiongkok, Jepang, dan Korea. Perkembangan SDM ini sendiri dapat diperoleh dari pendidikan dan keterampilan yang dimiliki penduduk Indonesia.

\section{Tantangan Sumber Daya Manusia untuk Indonesia}

Sejalan dengan keperluan untuk mempercepat penciptaan lapangan pekerjaan untuk populasi usia kerja (15-64 tahun), seperti yang dikutip dari International Monetary Fund (IMF), Indonesia juga perlu memperhatikan kualitas calon tenaga kerja yang dihasilkan. Hal ini disebabkan karena tingkat pengangguran yang tinggi ini sendiri mayoritas disebabkan oleh kualitas pendidikan penduduk rendah serta ketidakcocokan keterampilan dengan kebutuhan dunia (The Jakarta Post, 2018).

Hasil riset oleh IMF ini juga didukung oleh hasil studi dari The Global Talent Competitiveness Index 2020 (Lanvin, Bruno, dan Felipe, 2020) yang mengusung tema Global Talent in the Age of 
Artificial Intelligence. Indonesia ditempatkan pada negara dengan pendapatan rendah-menengah serta tidak masuk dalam kuartil teratas sehubungan dengan pilar-pilar yang diukur. Pada beberapa sub-pilar, seperti Akses ke Peluang Pertumbuhan dan Kemampuan Kerja, secara berurutan Indonesia berhasil menempati urutan ke-26 dan ke-30 dari 132 negara. Sebaliknya untuk sub-pilar Keterampilan Tingkat Tinggi dan Pengaruh dari Bakat yang merupakan bagian dari pilar Keterampilan Pengetahuan Global, Indonesia hanya menempati urutan ke-82 dan ke-84. Hal ini menyebabkan posisi Indonesia pada pilar Keterampilan Pengetahuan Global hanya berada pada urutan ke-84 dari 132 negara (Lanvin, Bruno, dan Felipe, 2020).

Berdasarkan latar belakang ini, kita dapat mengambil kesimpulan bahwa Indonesia sebenarnya memiliki peluang untuk berkembang menjadi negara maju, terutama karena adanya bonus demografi. Namun hal ini akan mustahil tanpa perencanaan dan implementasi yang terstruktur dan terarah, terutama dalam proses perkembangan kualitas SDM. Oleh karena itu, rumusan masalah yang akan diangkat pada tulisan ini ialah bagaimana strategi yang tepat dilakukan Indonesia dalam menyongsong bonus demografi agar dapat mencapai generasi emasnya?

Berdasarkan hal tersebut, penulis bertujuan untuk menggagas solusi berupa PAS: Pendidikan, Arahan, dan Sinergi menuju Indonesia Emas. Adapun tulisan ini diharapkan dapat bermanfaat untuk memberikan pemahaman terhadap penduduk Indonesia terkait bonus demografi dan apa yang dapat kita lakukan sebagai bagian dari periode ini. Selain itu, tulisan ini juga diharapkan dapat membantu Indonesia dalam menyongsong bonus demografi dengan lebih siap dengan memanfaatkan pendidikan yang bermutu dan institusi pemerintah yang kuat, keduanya disatukan dalam sinergi antara pemerintah dan penduduk Indonesia.

\section{Sustainable Development Goals untuk Indonesia Emas}

Sebagai sebuah tantangan yang dapat berdampak secara global, penulis menggagas sebuah solusi yang dinamakan PAS: Pendidikan, Arahan, dan Sinergi menuju Indonesia Emas. Ketiga pilar dari PAS, yaitu Pendidikan, Arahan, dan Sinergi merupakan turunan dari Sustainable Development Goals (SDG). SDG adalah tujuan yang ingin dicapai oleh dunia untuk menciptakan lingkungan dan kehidupan yang lebih baik. SDG terdiri dari 17 tujuan (goals) dan terbagi menjadi 169 target dengan sekitar 300 indikator sebagai pengukurnya (UN General Assembly, 2015). Ukuran dan indikator ini berbeda-beda sesuai dengan kebutuhan masing-masing negara. Sebagai kelanjutan dari MDG, SDG memuat 5 pondasi yaitu manusia, planet, kesejahteraan, perdamaian, dan kemitraan. Secara khusus, penulis akan membahas secara lebih spesifik terkait pendidikan, arahan, dan sinergi yang masingmasing berada di pilar ke-4, ke-16, dan ke-17 dari SDG sebagai solusi Indonesia dalam memanfaatkan bonus demografi secara lebih menyeluruh. 
Pilar pertama, yaitu pendidikan yang berkualitas (pilar ke-4 dari Sustainable Development Goals) menjadi salah satu poin penting dalam menyongsong bonus demografi. Tidak dapat dipungkiri bahwa pendidikan merupakan salah satu aspek yang membentuk karakter dan keterampilan Sumber Daya Manusia di Indonesia. Melalui pendidikan, tentu harapannya penduduk usia produktif sudah akan siap dalam memasuki dunia kerja. Hal ini sangat penting diperhatikan untuk memastikan pendidikan yang diberikan memang tepat sasaran sehingga sesuai dengan kebutuhan perkembangan ekonomi dan stabilitas di Indonesia. Jangan sampai nantinya lulusan yang ada tidak memiliki kesiapan dalam bekerja karena keterampilan yang dimiliki tidak sesuai dengan kebutuhan pasar dan menyebabkan mereka kesulitan mencari pekerjaan yang sesuai.

Lebih lanjut lagi, pendidikan yang dimaksud tidak tertutup pada pendidikan formal saja, namun juga dapat menyasar pada pendidikan kursus atau keterampilan dengan menekankan pada spesialisasi tertentu. Hal ini sendiri sudah diterapkan di Indonesia dengan adanya beberapa Sekolah Menengah Kejuruan (SMK) yang memang sudah terspesialisasi dan menghasilkan lulusan siap kerja. Kedepannya, bukan tidak memungkinkan apabila dapat diperbanyak lagi SMK yang memang menaungi beberapa keterampilan yang belum tersedia saat ini. Hal ini akan memberikan lebih banyak pilihan para siswa dalam menentukan jalur karir yang akan mereka tekuni.

Pilar kedua, yaitu institusi pemerintahan yang kuat (pilar ke-16 dari Sustainable Development Goals). Bonus demografi yang akan mengalami puncaknya pada tahun 2028-2031 memerlukan dukungan penuh dari institusi pemerintahan yang kuat dalam pemetaan dan perencanaan terstruktur terkait kebutuhan Indonesia dan dunia dalam 10 tahun ke depan. Pemetaan ini kemudian dijadikan landasan dalam penyusunan kurikulum pendidikan di Indonesia. Hal ini dapat membantu mempersiapkan Sumber Daya Manusia sebagai pilar dalam periode emas Indonesia dalam mempersiapkan diri baik untuk bersaing secara global.

Penyesuaian kurikulum ini perlu dilakukan pemerintahan dengan menyasar kepada para pemangku kepentingan, seperti pemilik bisnis dan wirausaha, dan dengan melakukan studi terkait tren perkembangan dunia secara global serta peluang terciptanya lapangan pekerjaan sesuai dengan profil lulusan. Dengan demikian, pemerintah akan memiliki dasar yang kuat dalam menentukan arah pemetaan keterampilan dan karakter yang diperlukan Sumber Daya Manusia Indonesia, terutama mereka yang berada di usia produktif, di tahun-tahun mendatang untuk dapat bersaing di kancah nasional dan internasional. Lebih lanjut lagi, institusi yang kuat ini juga dapat berperan dalam memastikan implementasi dan informasi yang dibutuhkan penduduk terkait bonus demografi dapat terlaksana dengan baik dan sesuai dengan standar.

Sejauh ini sendiri, sebenarnya sudah terdapat beberapa institusi pemerintahan yang melakukan sosialisasi terkait dengan bonus demografi, seperti misalnya Kominfo hingga Bappenas, pun beberapa 
pejabat pemerintahan juga sudah menyadari dan mengetahui pentingnya pemanfaatan periode bonus demografi ini. Namun, semua arahan yang mereka lakukan disosialisasikan secara independen tanpa keterikatan satu dengan lainnya. Hal ini menimbulkan ketidaksetaraan penyebaran informasi dan pemahaman di penduduk. Sehingga harapan kedepannya pun terdapat sebuah platform khusus dalam penyaluran informasi kepada penduduk terkait bonus demografi dan bagaimana penduduk Indonesia dapat berpartisipasi dalam menyukseskan periode ini.

Sedangkan pilar ketiga adalah sinergi (pilar ke-17 dari Sustainable Development Goals). Sinergi adalah kerja sama yang dibutuhkan antara institusi yang kuat, dalam hal ini pemerintah, dengan penduduk Indonesia. Hal ini merupakan pilar yang mengikat pilar pendidikan dan institusi yang kuat menjadi satu kesatuan. Sebagai pembungkus yang akan merekatkan pendidikan dan arahan, sinergi berperan dalam menyatukan keduanya agar berjalan dengan selaras. Pemerintah tidak dapat berjalan sendiri dalam menciptakan kurikulum dan kebutuhan penduduk tanpa melakukan pemetaan dan pemahaman terhadap pasar dan kebutuhan pemangku kepentingan dalam beberapa tahun ke depan. Pun sebaliknya, sekuat apapun penduduk Indonesia berusaha dalam memanfaatkan bonus demografi, mereka tidak akan bisa mencapainya dengan berjalan sendiri-sendiri. Sinergi berperan untuk memastikan terdapat keselarasan tujuan dan langkah-langkah yang diambil berbagai pihak untuk menciptakan harmoni.

Secara umum, ketiga pilar ini dapat menjadi landasan dalam menciptakan Sumber Daya Manusia yang siap dan mampu bersaing ketika dihadapkan dengan perubahan selama periode bonus demografi ini. Bekal berupa pendidikan keterampilan dan karakter dapat menghasilkan Sumber Daya Manusia yang mampu bersaing di dunia global. Sinergi yang berasal dari dorongan pemerintahan yang kuat dalam negosiasi dengan pemangku kepentingan, pengusaha, dan wirausaha juga dapat semakin memantapkan langkah penduduk Indonesia dalam memperoleh pekerjaan yang sesuai dengan profil lulusannya. Hal ini akan semakin meningkatkan stabilitas daya beli penduduk sehingga menciptakan lapangan usaha yang baru serta investasi dari dalam dan luar negeri.

\section{Siapkah Kita Bergerak Maju?}

Bonus demografi sesungguhnya adalah peluang bagi Indonesia untuk terus meningkatkan stabilitas dan pertumbuhan ekonominya. Namun, kita perlu sadar bahwa bonus demografi tidak akan bisa berjalan sendiri. Kita lah, sebagai penduduk negara Indonesia yang memiliki kemampuan untuk mengambil kesempatan ini untuk memajukan diri dan negara kita. Kita lah, yang dapat menentukan, ke arah mana akan kita bawa negara ini?

Pemaparan PAS: Pendidikan, Arahan, dan Sinergi menuju Indonesia Emas pun hanyalah sebuah solusi yang ditawarkan penulis untuk memaksimalkan periode bonus demografi yang sedang 
dialami Indonesia. Pendidikan adalah dasar dari pembentukan karakter dan Sumber Daya Manusia yang tentunya akan berpengaruh terhadap kesiapan kerja penduduk usia produktif. Pendidikan ini pun tidak hanya berarti pendidikan formal, namun juga dapat menyasar pada pendidikan kursus atau keterampilan dengan menekankan pada kesiapan penduduk usia produktif untuk bekerja.

Pendidikan sendiri tidak dapat berjalan dengan baik apabila tidak adanya arahan yang jelas dari pemerintah Republik Indonesia yang memegang kendali dalam kurikulum dan menyelaraskannya dengan kebutuhan pasar. Peran institusi yang kuat sangat besar dalam menentukan arah pemetaan keterampilan dan karakter yang diperlukan Sumber Daya Manusia Indonesia, terutama mereka yang berada di usia produktif, di tahun-tahun mendatang untuk dapat bersaing di kancah nasional dan internasional. Lebih lanjut lagi, institusi yang kuat ini juga dapat berperan dalam memastikan implementasi dan informasi yang dibutuhkan penduduk terkait bonus demografi dapat terlaksana dengan baik dan sesuai standar.

Sebagai pembungkus yang akan merekatkan pendidikan dan arahan, sinergi berperan dalam menyatukan keduanya agar berjalan dengan selaras. Pemerintah tidak dapat berjalan sendiri dalam menciptakan kurikulum dan kebutuhan penduduk tanpa melakukan pemetaan dan pemahaman terhadap pasar dan kebutuhan pemangku kepentingan dalam beberapa tahun ke depan. Pun sebaliknya, sekuat apapun penduduk Indonesia berusaha dalam memanfaatkan bonus demografi, mereka tidak akan bisa mencapainya dengan berjalan sendiri-sendiri. Sinergi berperan untuk memastikan terdapat keselarasan tujuan dan langkah-langkah yang diambil berbagai pihak untuk menciptakan harmoni. Ketiga poin ini apabila digabungkan, tentu dapat menjadikan Indonesia sebagai negara yang semakin maju dan stabil. Pertanyaannya, sudah siapkah kita untuk bergerak maju? 


\section{Daftar Pustaka}

Adinugroho, I., Dwifatma, A., Gani, E., \& Simartama, S. (2019). "Pandangan Kaum Muda Perkotaan terhadap Demokrasi di Tahun Politik 2019”. Jakarta: Institute of Public Policy Universitas Katolik Indonesia Atma Jaya.

Aditiasari, Dana. "RI Perlu Belajar Dari China Dan Korsel Soal Bonus Demografi." detikcom, 25 Juni 2015. https://finance.detik.com/berita-ekonomi-bisnis/d-2952133/ri-perlu-belajar-darichina-dan-korsel-soal-bonus-demografi.

Lanvin, Bruno, and Felipe Monteiro. "The Global Talent Competitiveness Index 2020 Global Talent in the Age of Artificial Intelligence," 2020, https://www.insead.edu/sites/default/files/assets/dept/globalindices/docs/GTCI-2020report.pdf.

LIPI. “Jumlah Usia Produktif Besar, Indonesia Berpeluang Tingkatkan Produktivitas.” 2014, 1 Maret 2020. http://lipi.go.id/berita/jumlah-usia-produktif-besar-indonesia-berpeluang-tingkatkanproduktivitas/15220.

"Many Countries in Asia Failing to Gain from Population Bonuses." Nikkei Asian Review, 2014, 12 April 2020. https://asia.nikkei.com/Economy/Many-countries-in-Asia-failing-to-gain-frompopulation-bonuses.

Setiawan, D. “Mengawal Bonus Demografi Indonesia - LPMP DKI Jakarta.” Kemdikbud.go.id, 14 Februari 2017, diakses dari https://lpmpdki.kemdikbud.go.id/mengawal-bonus-demografiindonesia/ pada 1 Maret 2020.

The Jakarta Post. “Commentary: Are We Heading Toward Demographic Bonus or Disaster?” The Jakarta Post, 2018. https://www.thejakartapost.com/academia/2018/03/05/commentary-are-weheading-toward-demographic-bonus-or-disaster.html.

Umah, Anisatul. “RI \& Korsel Dulu Sama-Sama Miskin, Kok Sekarang Beda Nasib?” news. cnbcindonesia.com, 20 September 2019. https://www.cnbcindonesia.com/news/20190920104500-4-100893/ri-korsel-dulu-sama-samamiskin-kok-sekarang-beda-nasib.

UN General Assembly. (2015). "Transforming our world: the 2030 Agenda for Sustainable

Development", 1 Maret 2020, A/RES/70/1, diakses dari http://www.refworld.org/docid/57b6e3e44.html.

Utomo, W. P. (2018). Indonesian Millennial Report. Jakarta: IDN Times.

Wicaksono, Pribadi. "Mahfud MD Sebut Politik Identitas Di Tahun Politik Ancam Bangsa." Tempo, 9 Januari 2019. https://nasional.tempo.co/read/1163077/mahfud-md-sebut-politik-identitas-ditahun-politik-ancam-bangsa. 